\title{
Structural analysis of inclined type subsoiler using CAD software
}

\section{R.G. JAKASANIA, A.L. VADHER AND R. YADAV}

Received : 24.01.2017; Revised : 25.02.2017; Accepted : 10.03.2017

See end of the Paper for authors' affiliation

Correspondence to :

R.G. JAKASANIA

Department of Farm Machinery and Power, College of Agricultural Engineering and Technology, Junagadh Agricultural University, JUNAGADH (GUJARAT) INDIA

Email : ronakjakasania92@ gmail.com
- ABSTRACT : Proper design of agriculture implements is necessary in order to increase their working life time and reduce the farming costs. In this study Creo and ANSYS software were used to carry out finite element analysis of inclined type subsoiler. 3D model of inclined type subsoiler was made using Creo software and static structural analysis of subsoiler was carried out using ANSYS software. The dimensions of inclined type subsoiler was selected as per local manufacturing database of subsoiler whereas loading condition defined by maximum draft force which was exerted on inclined type subsoiler in field. Results of simulation showed that maximum deformation was observed as $2.74 \mathrm{~mm}$ at the end of the share while maximum equivalent (von-mises) stress was $280.71 \mathrm{MPa}$ at the clamp. Maximum principal stress and maximum shear stress were found as 283.30MPa and 46.24MPa, respectively in subsoiler. The value of factor of safety was 1.25 and it was observed that factor of safety was very low so optimized design is required.

- KEY WORDS : CAD, Deformation, FEA, Stress, Subsoiler

- HOW TO CITE THIS PAPER : Jakasania, R.G., Vadher, A.L. and Yadav, R. (2017). Structural analysis of inclined type subsoiler using CAD software. Internat. J. Agric. Engg., 10(1) : 78-81, DOI: 10.15740/ HAS/IJAE/10.1/78-81. 